\title{
燃料の蒸留温度低下による 早期噴射形予混合圧縮着火機関の燃焼改善*
}

酒井 厚*1, 武山洋 之*2
小 英 之*1, 宮 本 登*1

\section{Combustion Improvements in an Early Injection Type Premixed Charge Compression Ignition Engine with Lower Distillation-temperature Fuels}

\author{
Atsushi SAKAI, Hiroyuki TAKEYAMA, \\ Hideyuki OGAWA*3 and Noboru MIYAMOTO \\ ${ }^{* 3}$ Division of Mechanical Science, Hokkaido University, \\ N13 W8, Kita-ku, Sapporo-shi, Hokkaido, 060-8628 Japan
}

\begin{abstract}
The CFD analysis showed that lower distillation temperature fuels improved evaporation of the fuel spray just after injection, resisted adhesion to the cylinder wall, and improved mixture homogeneity, probably due to its higher volatility. Analysis of components in the used lubricant oil indicated that a remarkable quantity of diesel fuel, corresponding to $7 \%$ of the total energy supply, was diluted to the lubricant oil when the fuel spray was allowed to impinge directly onto the cylinder wall. Lower distillation temperature fuel actually reduced fuel adhesion on the cylinder wall and prevents fuel dilution into the lubricant oil even with early injection when the fuel was allowed to impinge directly onto the cylinder wall. The deterioration in thermal efficiency that occured with advanced injection timing with ordinary diesel fuel was eliminated with the lower distillation temperature fuel without significantly altering the THC and CO emissions.
\end{abstract}

Key Words: Internal Combustion Engine, Premixed Combustion, Fuel, Distillation Temperature, CFD, Exhaust Gas Emissions, Lubricant Oil Dilution

\section{1. 緒}

早期噴射形の予混合圧縮着火機関では, 比較的低 温.低圧雲囲気内に燃料噴射を行うため, 燃料の蒸留 特性に対する要求が従来のディーゼル機関とは異なる ものと考えられる.たとえば, 軽油のような低蒸発性 㜣料を圧縮行程早期に噴射すると, 雲囲気がまだその 蒸留温度に達していないため,燃料の一部が未蒸発の まま燃焼室壁面に付着するとともに润滑油に混入する ことが報告されている(1).これに対し, 圧縮行程早期 の雲囲気やシリンタ壁面の各温度よりも蒸留温度が低 い燃料を用いることにより,噴霧および壁面付着燃料 の蒸発速度が増加し, 混合気の均一性向上と潤滑油一 の燃料混入回避とが期待できる.

本研究では,CFD解析によって早期噴射形予混合圧

\footnotetext{
* 原稿受付 2004 年 1 月 20 日.

*1 正員, 北海道大学大学院工学研究科(-060-8128 札幌市北 区北 13 条西 8 )

*2 北海道大学大学院工学研究科.

E-mail : h-ogawa@eng.hokudai.ac.jp
}

縮着火機関の混合気形成過程に対する燃料の蒸留特性 影響を解明するとともに, 実験により低蒸留温度燃料 利用による機関性能およひ排気エミッションの改善効 果について検討した.

\section{2. 実験装置および方法}

実験には, 水冷・単気筒・四サイクルの直噴式 ディーゼル機関 (Nissan Diesel, PE-1)を用いた.その主 要諸元は, 行程体積 $1950 \mathrm{~cm}^{3}$, ボア・ストローク $133 \mathrm{~mm}$ x $140 \mathrm{~mm}$, スワール比 2.2 である.EGRは排気の一部を 分流·冷却して吸気と合流させることにより行った. 然料噴射系にはコモンレール式然料噴射システムを用 い, 噴射圧力は $120 \mathrm{MPa}$ 設定した. 供試然料はJS特 3号軽油と, 低蒸留温度燃料としてノルマルヘプタン 単体,およびノルマルヘプタンとイソオクタンの混合 㜣料を使用した. 各燃料の基本性状を表 1 に示す. 燃 焼室形状はキャビティ径深さが $70 \mathrm{~mm} / 33 \mathrm{~mm}, 80 \mathrm{~mm}$ $25 \mathrm{~mm}, 90 \mathrm{~mm} / 20 \mathrm{~mm}$ の 3 種類の皿形燃焼室を使用し圧 䄸比はすべて14(供試機関本来は18)とした.噴射ノズ 
Table 1 Properties of the Tested fuels

\begin{tabular}{|c|c|c|c|}
\hline & Diesel fuel & n-Heptane & iso-Octane \\
\hline $\begin{array}{c}\text { Density } \\
\left(\mathrm{g} / \mathrm{cm}^{3}\right)\end{array}$ & 0.82 & 0.68 & 0.69 \\
\hline $\begin{array}{c}\text { Lower calorific value } \\
(\mathrm{MJ} / \mathrm{kg})\end{array}$ & 43.2 & 44.6 & 43.2 \\
\hline $\begin{array}{c}\text { Boiling point } \\
\text { ( }{ }^{\mathrm{C})}\end{array}$ & $\begin{array}{c}289 \\
\left(\mathrm{~T}_{50}\right)\end{array}$ & 98.4 & 99.3 \\
\hline Cetane number & 50 & 56 & 12 \\
\hline $\begin{array}{c}\text { Theoretical air-fuel ratio } \\
(\mathrm{kg} / \mathrm{kg})\end{array}$ & 14.8 & 15.2 & 15.1 \\
\hline
\end{tabular}

ルは原則として噴霧間角度 $40^{\circ}$ の四孔ホールノズル $(\phi 0.21 \mathrm{~mm})$ を使用したが, 潤滑油への燃料混入量を計

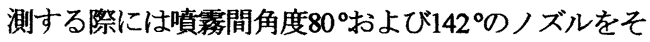
れぞれ使用した。機関運転条件は，燃料噴射量を 1.4 $\mathrm{kJ} / \mathrm{stroke}$ (いずれもEGRなしの場合で当量比 0.21 に相 当), 回転速度を $1200 \mathrm{rpm}$, 冷却水入口温度を $80^{\circ} \mathrm{C}$ と した.

\section{3. 混合気形成過程の CFD 解析}

実験に先立ち,CFD解析によって非燃焼時における 早期噴射形予混合圧縮着火機関の混合気形成過程に対 する燃料の蒸留特性影響について検討した。

3.1 解析方法 CFD コードはFIREであり, 噴霧モ ジュールDiscrete Droplet Method (DDM) ${ }^{(2)}$, 分裂モデル

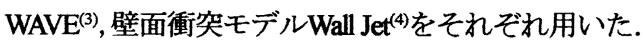
解析では燃料の蒸留特性のみの影響を検討するため, 軽油, ノルマルデカン, ノルマルオクタン, ノルマル ヘプタンの温度一飽和蒸気圧特性を与えるとともに， 粘度あるいは密度などの蒸留特性以外の性状をあえて 軽油の性状と同一に固定した. 図1に各燃料の温度一 飽和蒸気圧特性をシリンダ内平均温度, 圧力線図と合 わせて示す.機関諸元は原則として供試機関と同一と し,燃焼室形状は供試機関と同一の皿形に,また噴射 ノズルは噴霧間角度 $40 \circ の$ 四孔ホールノズルにそれぞ れ設定した.また,燃焼室およひ噴射ノズル中心は図 2に示す供試機関と同一に設定した.

\section{2 燃料の蒸留温度が混合気分布に与える影雾}

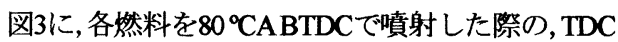
における混合気の燃料質量割合と当量比との関係を示 す.なお,図は蒸発燃料のみの質量割合であり未蒸発 然料は含まれていない.この場合, 燃焼室形状はキャ ビティ径 $70 \mathrm{~mm}$, 媣さ $33 \mathrm{~mm}$ の梁皿形であり, 大部分 の燃料噴霧はピストンキャビティの底部あるいは側壁 部に衝突する.各燃料とも,TDCまで圧縮が進行して も $\phi>1$ の過濃混合気が数パーセント存在しており, 低蒸留温度燃料を用いたとしてもここの噴射時期では

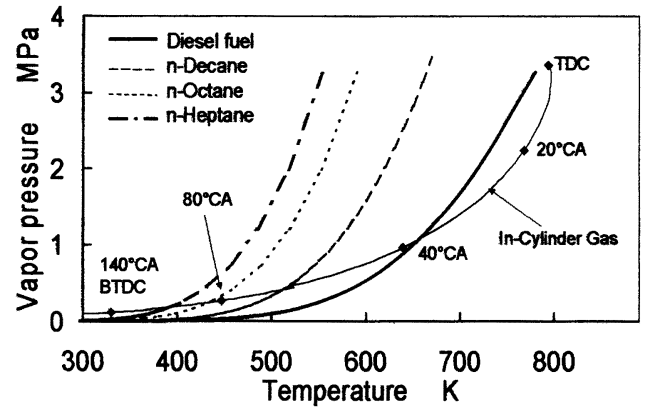

Fig. 1 Vapor pressure vs. temperature for analized fuels

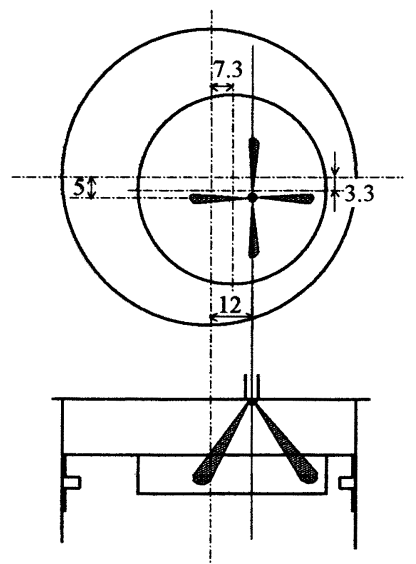

Fig. 2 Location of injection nozzle and combustion chamber

十分な希薄均一化が得られないことがわかる.しかし 蒸留温度の低いルマルオクタンやノルマルヘフタン では $\phi>2$ の超過濃混合気量が若干少なくなっている. また, $\phi=0.4$ 近傍の希薄混合気量は蒸留温度の低下に 伴い増加し,均一性の向上が若干認められるものの, その程度は大きくはない。

図4に,軽油およびノルマルヘプタンを噴射した際 の, 燃焼室内の断面における蒸発燃料の当量比分布

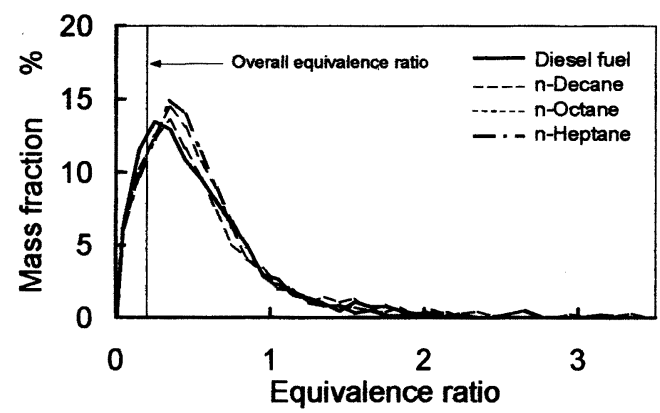

Fig. 3 Fuel mass fraction in each equivalence ratio of mixture at TDC with early injection

(Injection timing : $80^{\circ} \mathrm{CA}$ BTDC, Cavity dia.: $70 \mathrm{~mm}$ ) 
を,また図5に, その際の各当量比での混合気燃料お よび未蒸発燃料の質量割合をそれぞれ示す。なお, 図 4は, 噴霧の影響をより明確にするため,ノズル中心 を通る噴霧軸上断面の当量比分布を示したが,他の断 面においても同様の分布を示している.

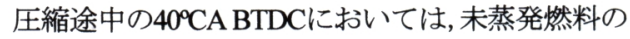
割合が軽油では30\%強と高いのに対し,ノルマルヘプ タンでは $5 \%$ に減少している. 図4の当量比分布にお いてノルマルヘプタンの方が濃混合気の部分が多く認 められるが,これは噴霧の蒸発が活発なためであり, 燃料噴射後 $40^{\circ} \mathrm{CA}$ 経過したこの時点でも混合気分布に 与える燃料蒸留温度の影響はまだ大きいことがわか る. また, 程度の差こそあれ, 両燃料とも燃焼室底部 に濃い混合気が形成されているのがわかる.

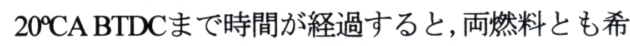
薄化が進行するものの, この時点でもなお濃混合気が 燃焼室底部に若干残留し,この傾向はTDCに至るまで 持続している. しかしTDCでは, 軽油の蒸発もかな り進むため,燃料の蒸留温度による混合気分布の差異 は縮少する.したがって,噴霧がキャビティ内壁に衝 突する $80^{\circ} \mathrm{CA}$ BTDCの噴射では, 然焼室内の混合気均 一化の程度は必ずしも十分高くはなく，また着火が TDCよりも余程早く生じない限り燃料蒸留温度低下に よるその改善効果も比較的小さいものと言える.

燃料噴射を $140^{\circ} \mathrm{CABTDC}$ と更に進めた際の, TDCに おける混合気の燃料質量割合と当量比との関係を図6 に示す.この場合, 幾何学的には噴射燃料のほとんど がキャビティ外のピストン頂面に衝突する.いずれの 燃料においても, 前述の $80^{\circ} \mathrm{CABTDC}$ 燃料噴射に比べ て希薄均一化が進んでおり, 平均当量比 ( $\phi=0.21)$ 近

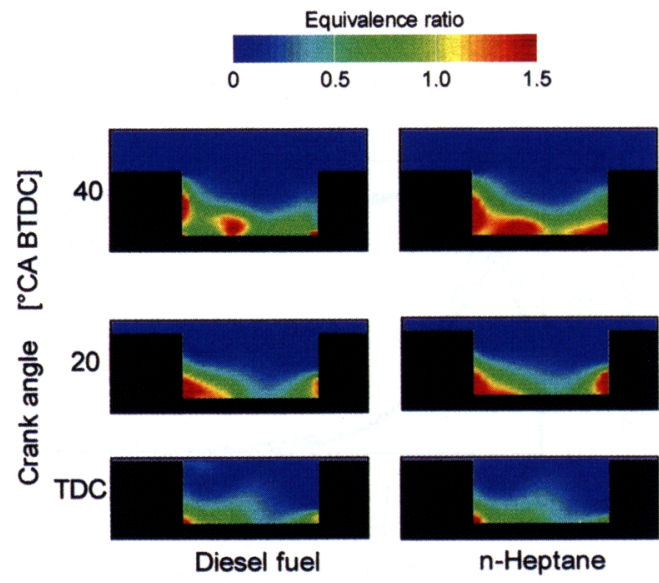

Fig. 4 Distribution of equivalence ratio in combustion chamber with early injection

(Injection timing : $80^{\circ} \mathrm{CA}$ BTDC, Cavity dia.: $70 \mathrm{~mm}$ )

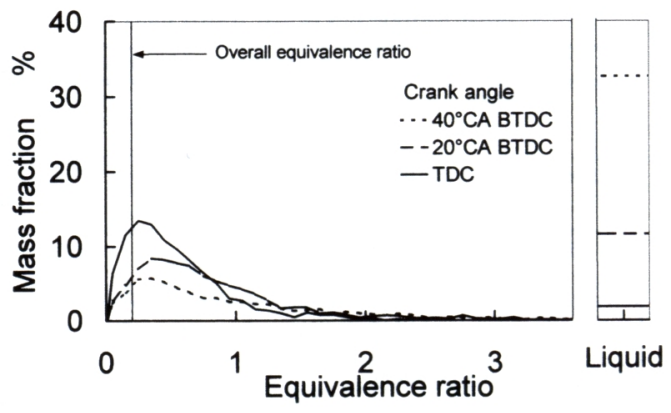

(a) Diesel fuel

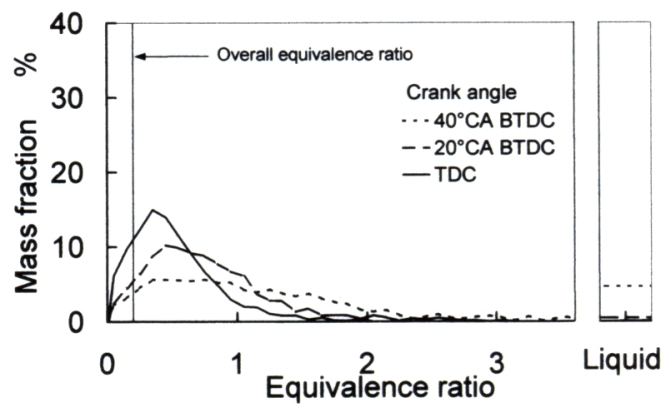

(b) n-Heptane

Fig. 5 Fuel mass fraction in each equivalence ratio of mixture and unvaporized fuel with early injection

(Injection timing : $80^{\circ} \mathrm{CA}$ BTDC, Cavity dia.: $70 \mathrm{~mm}$ )

傍に大きなピークの存在がわかる. とくに, 0.6から 1.0 当量比域での質量割合が蒸留温度の低下にとも ない明らかに減少している.

図7に,軽油およびノルマルヘプタンの燃焼室内当 量比分布を, また図 8 に, その既蒸発燃料割合の時 間推移をそれぞれ示す。この場合, $80^{\circ} \mathrm{CABTDC}$ 燃料 噴射時に比べて更に低温・低圧下での噴射であるた め, 蒸発性の悪い軽油では混合気形成量が減少し, と くに燃料噴射終了直後の $120^{\circ} \mathrm{CABTDC}$ C゙は燃料間の 混合気分布に大きな差が認められる.この場合, 噴霧

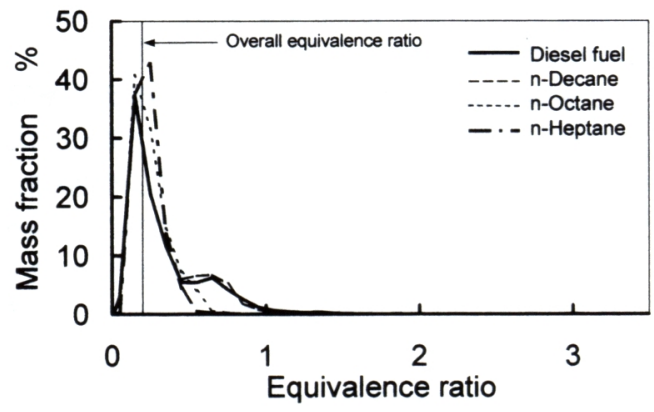

Fig. 6 Fuel mass fraction in each equivalence ratio of mixture at TDC with earlier injection

(Injection timing : $140^{\circ} \mathrm{CA} \mathrm{BTDC,} \mathrm{Cavity} \mathrm{dia.:} 70 \mathrm{~mm}$ ) 
のほとんどがキャビティ内に入らずピストン頂部に衝 突している.キャビティ外に噴射された燃料はピスト ン上部に滞留し, ピストンの上昇とともにキャビティ 内一徐々に流入するが, 軽油の場合, 噴霧の蒸発速度 が遅いためにこの部分の混合気形成が遅く, TDCに 至ってもスキッシュエリア部に量論比近傍の混合気が 残留している.この領域に混合気が形成されると,消 炎作用により熱効率の悪化やTHC排出量の増加が眯 念される.一方, 蒸発速度の速いノルマルヘプタンで は, $80^{\circ} \mathrm{CABTDC}$ 時点で噴射燃料の $90 \%$ 以上が蒸発し,

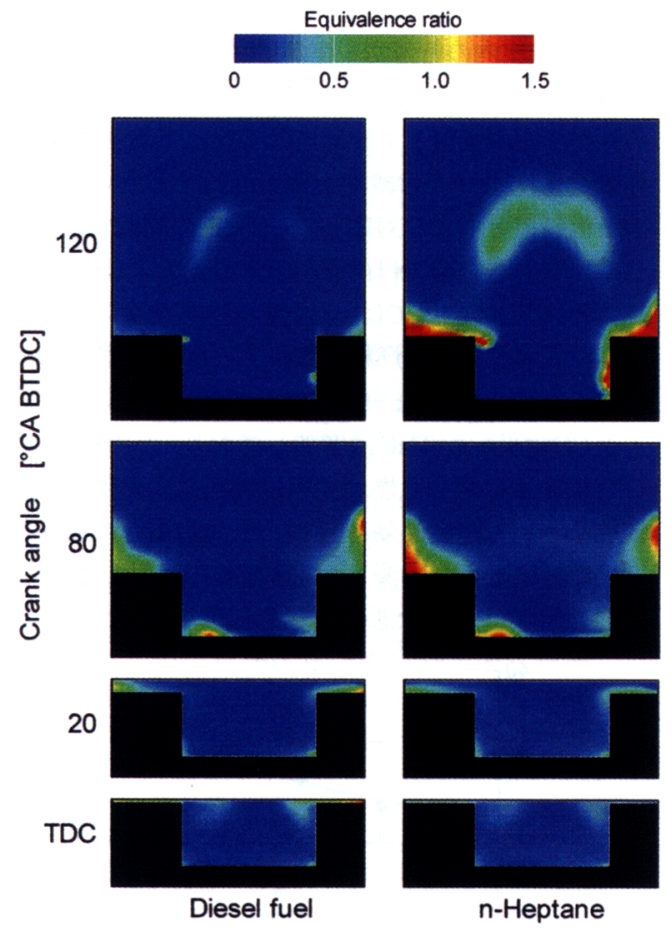

Fig. 7 Distribution of equivalence ratio in combustion chamber with earlier injection

(Injection timing : $140^{\circ} \mathrm{CA}$ BTDC, Cavity dia.: $70 \mathrm{~mm}$ )

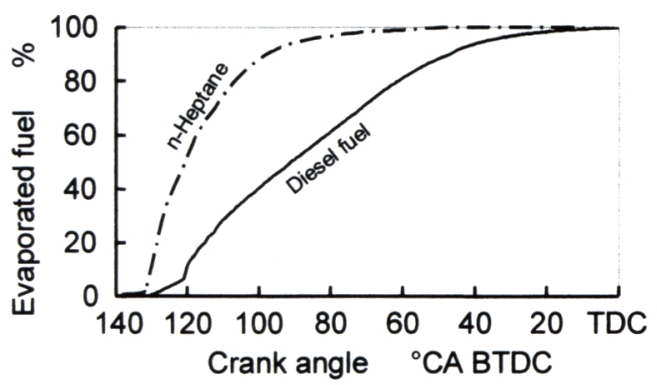

Fig. 8 Transition of evaporated fuel faction in diesel fuel and n-Heptane

(Injection timing : $140^{\circ} \mathrm{CA}$ BTDC, Cavity dia.: $70 \mathrm{~mm}$ )
その後ピストン上部およびライナ壁近傍の混合気は キャビティ内に流入しつつ希薄化している.このよう に早期の噴射によりピストンキャビティ外に噴射され た噴霧の混合気分布は,燃料の蒸留温度の影響を比較 的大きく受ける.ここでは軽油とノルマルヘプタンに つい詳細に解析を行ったが,このスキッシュエリア 部の混合気は図6における主に当量比0.6から1.0の領 域に対応し, その混合気は蒸留温度の低下にともなっ て著しく减少しノルマルヘプンではほとんど存在し ない.

3.3 燃狫室キャビティ径 / 深さが混合気分布に 与える影䈏前節の結果から, 噴射時期の早期化 は混合気の均一化促進に有効であるが, ピストンキャ ビティ外に噴射される燃料量の増加が弊害になる可能 性を示した. また, 混合気は燃焼室底部に分布しがち であり,深皿形燃焼室では燃焼室上下方向に層状分布 する傾向が認められた.このことは,均一混合気形成 の点から大口径浅皿燃焼室がより有利であることを示 唆している. そこで燃焼室容積を同一とし, キャビ ティ径を $70 \mathrm{~mm}$ から $90 \mathrm{~mm}$ に拡大した大口径浅血形燃 焼室(深さ20mm)を用いて比較検討を行った.

図9に, 両燃焼室において $80^{\circ} \mathrm{CA}$ BTDCで軽油およ びノルマルヘプタンを噴射した際の, TDCにおける混 合気の燃料質量割合と当量比との関係を示す.燃料の

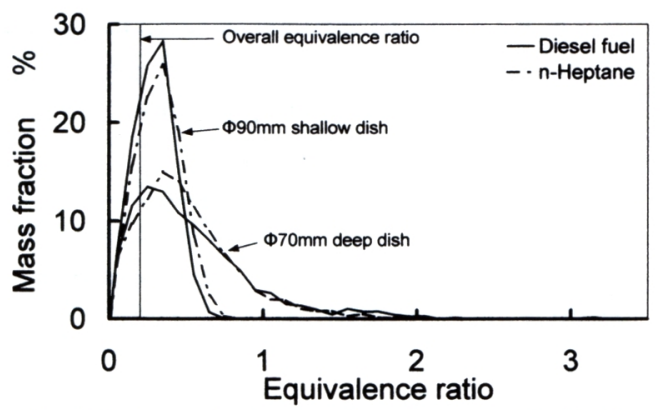

Fig. 9 Fuel mass fraction in each equivalence ratio of mixture at TDC for different cavities with early injection (Injection timing : $80^{\circ} \mathrm{CA} \mathrm{BTDC}$ )

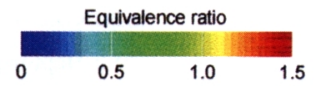

Diesel fuel
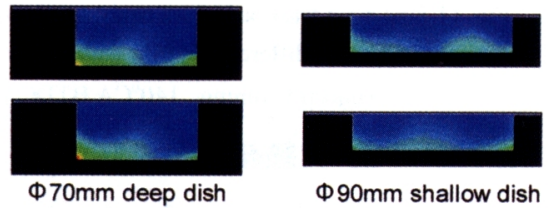

$\$ 70 \mathrm{~mm}$ deep dish

Ф90mm shallow dish

Fig. 10 Distribution of equivalence ratio in combustion chamber at TDC for different cavities with early injection (Injection timing : $80^{\circ} \mathrm{CA} \mathrm{BTDC}$ ) 
如何に拘わらず,燃焼室の大口径浅血化により混合気 の均一化が大きく改善されることがわかる.更に,図 10にその際の燃焼室内の当量比分布を示すが, 両然料 とも浅皿化により燃焼室底部の濃混合気が消㓕すると ともに,キャビティ上部の超希薄領域の規模も减少し ている.

図11に, $140{ }^{\circ} \mathrm{CABTDC}$ 噴射時での混合気の燃料質 量割合を示す.大口径化によって,スキッシュ領域に 侵入する燃料が減少するため, 軽油の場合当量比 0.5 以上の比較的濃い混合気が堿少している. それに対 し,ノルマルヘプタンでは燃焼室形状の影響を大きく は受けておらず,キャビティ外に噴射された場合でも 当量比 0.5 以上の混合気形成は少なくなっており, 比 較的良好の混合気形成が期待できる.この結果は,低 蒸留温度燃料の使用により噴射ノズルや燃焼室形状の 設計時における自由度の増加を意味し,たとえば多段 噴射形の予混合圧縮着火燃焼(5)(の)では様々な噴射パ ターンに対する幅広い適応の可能性を示唆している。

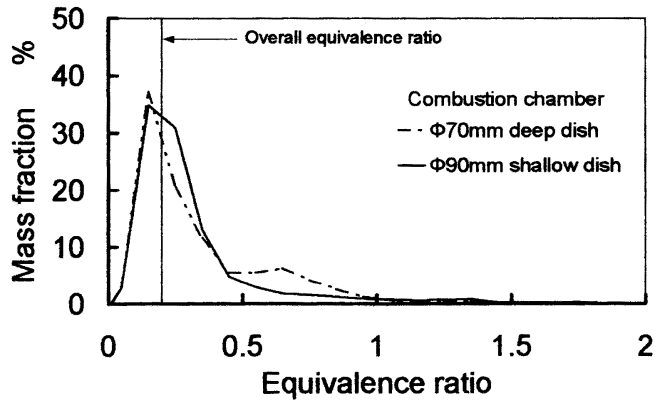

(a) Diesel fuel

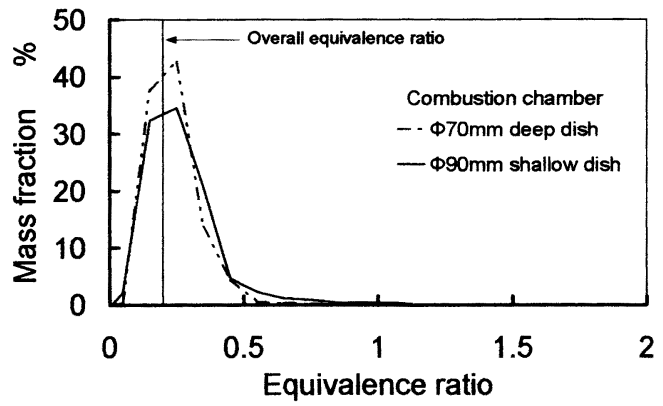

(b) n-Heptane

Fig. 11 Fuel mass fraction in each equivalence ratio of mixture at TDC for different cavities with earlier injection (Injection timing : $140^{\circ} \mathrm{CA} \mathrm{BTDC}$ )

\section{4. 実験結果および考察}

$4 \cdot 1$ 低蒸留温度燃料によるエミッションと熱効 率の改善 低蒸留温度燃料による予混合圧縮着火 燃焼を軽油の場合と比較することにより,燃料の低蒸
留温度化による機関性能とエミッション改善効果につ いて検討した.低蒸留温度燃料としてノルマルヘプタ ンを使用したが,その際,供試機関での予混合圧縮着 火燃焼において着火時期が軽油と同一になるように， ノルマルヘプタと蒸留温度が同一で,着火性の低い イソオクタンを混合し,ノルマルヘプタン $75 \%$ ーイソ オクタン $25 \%$ (オクタン価25)の混合然料を低蒸留温度 燃料として用いた。

図 12に, 燃料噴射時期に対する図示熱効率と排気 エミッションを示す.燃料噴射時期が $120^{\circ} \mathrm{CABTDC}$ り遅延すると,両然料ともNOxは著しく悪化すること から，燃焼室内の希薄均一化が確保されなくなること

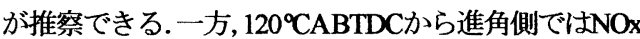
のレベルが両然料とも非常に低くなっており，噴射時 期の進角によって希薄均一化が進行するというCFD の解析結果ともよく対応している.この超低NOxとな る燃料噴射進角時では両然料ともTHCおよびCOが増 加する.CFDの結果では, ノルマルヘプタンの方がス キッシュエリア部の燃料が堿少するため,未燃成分の 低减が期待されるが, 実際には低蒸留温度燃料を用い るとCOは低いがTHCは增加しており，このCOおよ びTHCを基に求めた燃焼効率は燃料による差異が比 較的小さい. 図示熱効率 $\eta_{i}$ は, 軽油の場合は噴射時 期の進角にともない著しく悪化するのに対し,低蒸留 温度然料では大きな悪化が認められない.なお,これ

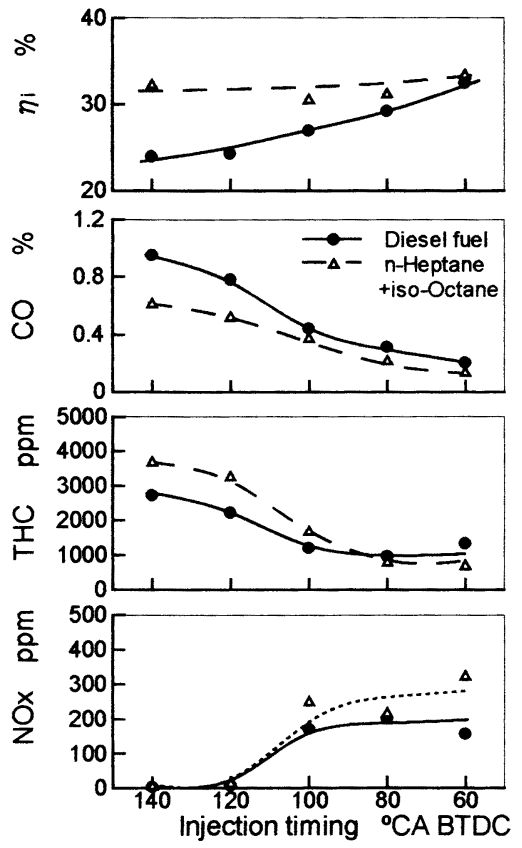

Fig. 12 Effect of lower distillation-temperature fuel on $\eta_{\mathrm{i}}$ and emissions (EGR : $40 \%$ ) 
らすべての条件で黒煙(ボッシュ濃度)は $0 \%$ 以下で あった。

図13に, 図120噴射時期 $140^{\circ} \mathrm{CABTDC}$ 対応する 指圧線図およひ熱発生率を示す.低蒸留温度燃料に比 較して軽油では熱発生量が少ないことから,燃焼に寄 与しない燃料の割合が多いことが明らかである.上述 のように, 両燃料間で排気組成から求めた燃焼効率に

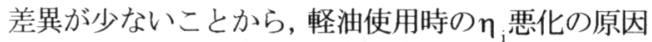
は, 主として燃料のライナ壁面付着による潤滑油への 混入によるものと考えられる。

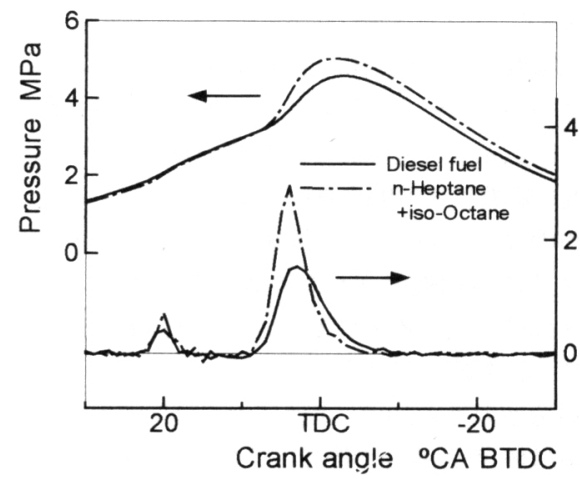

Fig. 13 Effect of lowe: distillation-temperature fuel on indicator and ROHR diagrams

(Injection timing : $140^{\circ} \mathrm{CA}$ BTDC, EGR : $40 \%$ )

\section{2 燃料の低蒸留温度化による淍滑油への燃料混}

入量低娍 そこで予混合圧縮着火燃焼において軽 油とノルマルへプタンを使用した際の潤滑油への燃料 混入について検討した。混入然料量は, EGR率 $0 \%$ の 定常運転(当量比 $\phi=0.21$ ) において, 運転開始前から 1時間間隔で潤滑油を $50 \mathrm{~cm}^{3}$ ずつ採取・分析すること により求めた。燃料噴射ノズルには噴霧間角度が $80^{\circ}$ と $142^{\circ}$ の2種類を使用したが, $60^{\circ} \mathrm{CABTDCでの}$ 燃料噴射では, 噴霧間角度 $80^{\circ}$ のノズルでの噴霧は幾 何学的にキャビティ底部に衝突するのに対し, $142^{\circ}$ で はシリンダライナに直接衝突する.

図14に, 潤滑油への燃料混入量の時間推移を示す。 シリンダライナに直接衝突する早期噴射(噴射時期 60 ${ }^{\circ} \mathrm{CA} \mathrm{BTDC}$, 噴霧間角度 $142^{\circ}$ ) の場合, 軽油では混入 量が時間に対して直線的に増加するのに対し, 同じ条 件でのノルマルヘプタンでは, 潤滑油内のノルマルヘ プタンがほとんど検出されておらず,燃料の低蒸留温 度化による潤滑油への燃料混入の低減が明らかであ る.軽油であっても, シリンダ壁に直接衝突しない噴 霧間角度 $80^{\circ}$ の場合には, 潤滑油への燃料混入はほと んど認められない.

図15に, 図14の各条件におけるエネルギ一勘定を

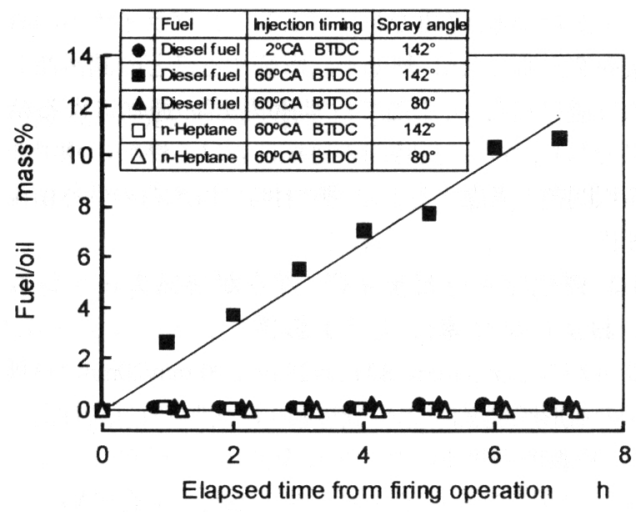

Fig. 14 Effect of lower distillation-temperature fuel on fuel dilution into lubricant oil (EGR : $0 \%$ )

示す. 図中下から, 指圧線図より求めた図示仕事, 潤 滑油一の燃料混入による損失 (軽油の早期噴射, 噴霧 間角度 $142^{\circ}$ のみ), THCおよぴCOの排出量から算定 した不完全燃焼損失, 排気へのエネルギ一損失, およ びその他の損失（大部分が椧却損失）である.なお， 排気へのエネルギー損失は, 理論熱効率より求めた值 に, 等容度の低下による損失分も加味して算出した。 軽油の早期噴射でシリンダライナに燃料が衝突した場 合には, 潤滑油への燃料混入損失が全投入エネルギー の 7\%にも達しており，熱効率低下の大きな原因に なっていると言える.一方，ノルマルヘプタンでも， 噴霧をシリンダ壁に衝突させると不完全燃焼損失が増 加し, 高い熱効率は得られていない, 早期噴射四者の 排ガスエネルギー損失は同程度であり, 通常のディー ゼル燃焼よりも若干小さくなっていることからも, 不 完全然焼損失の低㺂が熱效率向上の点から重要である

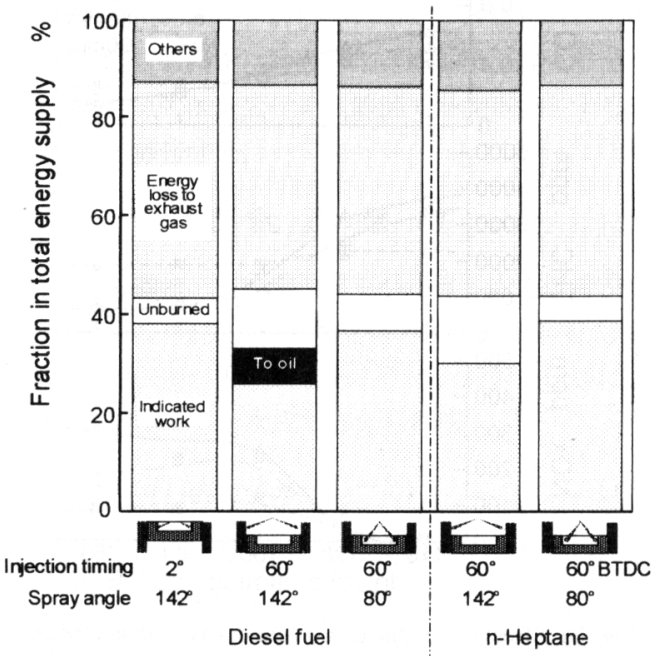

Fig. 15 Energy balances for several fuel injection conditions (EGR : 0\%) 
ことがわかる.軽油であってもシリンダライナへの直 接衝突を避ければ,熱効率に影響するほどの潤滑油混 入は避け得るが,ここでは7時間程度の運転による結 果であり,さらに長時間の運転における燃料の潤滑油 希釈問題を考虑すると早期噴射時には燃料の低蒸留温 度化が不可欠と考えられる。

$4 \cdot 3$ 燃焼室キャビティ径/深さが排気エミッショ ンおよび熱効率に及ほす影霎キャビティ径/ 深さが $70 \mathrm{~mm} / 33 \mathrm{~mm}, 80 \mathrm{~mm} / 25 \mathrm{~mm}, 90 \mathrm{~mm} / 20 \mathrm{~mm}$ の3種 類の皿形燃焼室について燃焼および排気特性を検討し た. 噴霧間角度 40 ののノズルを使用し, 㜣料はノルマ ルヘプタン $75 \%$ ーイソオクタン $25 \%$ の混合燃料を用 いた.

図16に, キャビティ径深さがグおよび排気エミッ ションに及ぼす影響を示す.キャビティ径70 mmおよ び80 mmの場合, 燃料噴射時期が $100^{\circ} \mathrm{CABTDC} よ り$ 進 角側では, 幾何学上噴射噴霧がキャビティ外に噴射さ れるため, THCが急激に悪化する傾向が明らかであ る.一方, $90 \mathrm{~mm}$ の広口径でのエミッションは燃料噴 射時期の影響を若干受けにくくなっている.この場 合, 遅角側に拈いて図9で示したとおり, 予混合気の 希薄均一化が他のキャビティよりも進行し過薄領域が 増大するため, THCが他の二者よりも高くなってい る.この場合のNOxは,キャビティ径の拡大にともな

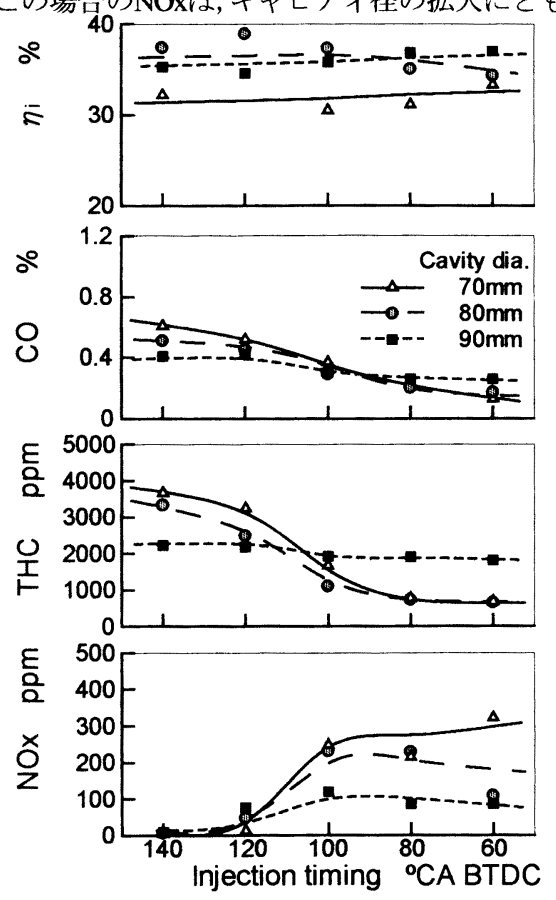

Fig. 16 Effect of combustion chamber cavity diameter on $\eta_{i}$ and emissions

(EGR : $40 \%$, n-Heptane+iso-Octane, Spray angle: $40^{\circ}$ )
う混合気の均一化促進により大幅な改善効果が認めら れる.また,キャビティ径拡大により混合気の均一化 が促進され量論近傍混合気が堿少するため, 着火時期 が遅延してTDCに接近し等容度が向上する.このた め, THCおよびCOの増加により燃焼効率が低下して いるにもかかわらず, 図示熱効率 $\eta_{i}$ の改善が得られ たものと考えられる.

\section{5. 結}

本研究で得られた結果を要約すると,およそ以下の 通りである.

1. 早期噴射された燃料は, 蒸留温度が高いほど初期 の蒸発が遅れるが, キャビティ内に噴射された場 合には上死点付近の混合気濃度分布に及ぼす蒸留 温度の影響は比較的小さい.

2. 軽油のような高蒸留温度燃料では, 燃焼室キャビ ティ外に早期噴射された噴霧がピストンスキッ シュ部に滞留するのに対し, 燃料蒸留温度低下に よりこれを解消できる。

3. 燃料蒸留温度の如何に拘わらず, 早期噴射時の混 合気は燃焼室底部に滞留しがちであるが, 燃焼室 の大口径浅血化は混合気の均一化に有効である.

4. 燃料の低蒸留温度化は排気エミッションの改善に さほど大きく寄与しないが, 燃料噴霧のライナ壁 面付着に起因する潤滑油内一の燃料混入を著しく 抑制し、これが熱効率改善の要因となる.

本研究の遂行に当たり, 北海道大学学生 大畑義幸 君に協力を得た.ここに謝意を表する.

\section{参考文献}

(1) 原田 明, ほか2名, 直接噴射式予混合圧縮着火 機関の運転領域と燃焼特性に関する研究, 日本機 械学会論文集(B偏), 67卷-653号 (2001), p.49-55.

(2) Dukowicz,J.K., A Particle Fluid Numerical Model for Liquid Spray, SAE Paper 970641, (1997)

(3) Bose,A.K.,Pei,C.T., Evaporation Rates in Spray Drying, Can.J.Chem.,42,252,(1964)

(4) O'Rourke,P.J., Statistical Properties and Numerical Implementation of a Model for Droplet Dispersion in Turbulent Gas, J.Comput.Physics, Vol.83, No.2(1989), p. $345-360$

(5) 小川英之, ほか2 名, 燃料の軽質化による二段噴射 予混合圧縮着火機関の燃焼改善, 自動車技術会秋 季大会学術講演会前刷集, No.93-02,p.15-18(2002)

(6) 橋詰 剛, ほか2名, 二段燃焼によるディーゼル機 関の排気改善, 日本機械学会論文集(B偏), 65巻631 号(1999), p.1166-1172. 